Natalia Długosz

Uniwersytet im. Adama Mickiewicza, Poznań

natrek43@gmail.com

\title{
O DYFUZJI SEMANTYCZNEJ W TEKSTACH DZIENNIKARSKICH NA PRZYKŁADZIE WYBRANYCH POLSKICH COMPOSITÓW Z PIERWSZYM OBCYM KOMPONENTEM ${ }^{1}$
}

Słowa klucze: dyfuzja semantyczna, tekst dziennikarski, pragmatyczne aspekty słowotwórstwa, composita bezafiksalne

Keywords: semantic diffusion, journalistic text, pragmatic aspects of word formation, affixless compounds

Do podjęcia problemu zakreślonego w tytule artykułu skłoniła mnie praca Aleksandra Kiklewicza Dyfuzja semantyczna w języku i tekście (Kiklewicz 2006a, b). Badacz zwraca uwagę na ekspansywny charakter dyfuzji semantycznej zwłaszcza w komunikacji masowej, upatrując źródła poszerzania się tego zjawiska w kulturze postmodernizmu,

[...] dla której charakterystyczne jest pierwszeństwo pragmatyki nad semantyką: funkcja informacyjna tekstów [...] coraz bardziej ustępuje przed funkcją oddziałującą czy też kształtującą [...] (Kiklewicz 2006b: 19).

Zjawisko, o którym mowa, ma charakter wieloaspektowy i może być rozpatrywane na różnych poziomach systemu językowego. W niniejszym artykule skupiam

$1 \quad$ Niniejsza praca powstała w ramach projektu Najnowsze złożenia bezafiksalne w języku polskim i bułgarskim, którym kieruję. Projekt został sfinansowany ze środków Narodowego Centrum Nauki przyznanych na podstawie decyzji numer DEC-2013/11/B/HS2/02867. 
uwagę na przejawach dyfuzji semantycznej w słowotwórstwie w kontekście niedookreślonego charakteru wielu tworzonych seryjnie i przez analogię złożeń z pierwszym komponentem obcym w języku polskim.

Teza o przewadze funkcji pragmatycznej nad funkcją semantyczną znajduje odzwierciedlenie w wynikach badań słowotwórczych prowadzonych na tekstach prasowych i reklamowych. Na pragmatyczny aspekt derywatów w rzeczywistości językowej współczesnej komunikacji medialnej zwracają uwagę m.in. Iwona Kaproń-Charzyńska (2007), Barbara Kudra (2011), Ewa Rogowska-Cybulska (2013) i Natalia Długosz (w druku), pisząc już nie tylko o pragmatycznej funkcji formatów, ale wręcz o derywacji i derywatach pragmatycznych (por. Kudra 2011; Długosz, w druku). Jak zauważa B. Kudra:

Słowotwórstwo w mediach jest dziś ukierunkowane pragmatycznie. Dynamika i jakość procesów słowotwórczych w komunikacji medialnej uwarunkowane są głównie czynnikami zewnątrzjęzykowymi, w tym wypadku przeobrażeniami w sytuacji komunikacyjnej mediów: wielość kanałów i kodów przekazu wymusza dużą konkurencyjność w walce o odbiorcę (Kudra 2011: 14).

Przewaga funkcji pragmatycznej nad nominatywno-informacyjną w derywatach słowotwórczych w tekstach medialnych często pociąga za sobą naruszenie warunku poprawności językowej, którego spełnienie niweluje do minimum stopień zakłóceń komunikacyjnych i umożliwia jednoznaczne rozumienie komunikatu przez odbiorcę. Natomiast słowotwórstwo w mediach jest z założenia nienormatywne: w derywatach o funkcji pragmatycznej normy są łamane (Kudra 2011: 15). Odpowiednio dobrane derywaty słowotwórcze w tekstach dziennikarskich stają się zatem narzędziem, za pomocą którego nadawca realizuje swoje doraźne potrzeby. Chodzi zwłaszcza o nadanie wypowiedzi cechy atrakcyjności. Tekst ma przyciągać uwagę odbiorcy dzięki temu, że jest nieszablonowy, że łamie pewne konwencje. Do tego celu wykorzystywane są zwłaszcza derywaty o skondensowanym znaczeniu, do których niewątpliwie można zaliczyć wiele compositów z pierwszym obcym komponentem. Bazują one na utwierdzonym w języku modelu słowotwórczym, opartym na analogii (więcej: Długosz 2014). Charakteryzuje je seryjność, polegająca na powtarzalności pierwszego komponentu złożenia w wielu derywatach. Zasadniczo w odniesieniu do tego typu struktur mowa jest o dwu podstawach słowotwórczych, z których pierwsza ulega ucięciu. Podstawy połączone są bezspójkowo, bez użycia dodatkowych środków słowotwórczych. Struktury te charakteryzuje łatwa rozkładalność na komponenty. Jednorodny jest typ relacji między komponentami: pierwszy z komponentów złożenia pełni funkcję określającą względem drugiego z komponentów. Są to jednak derywaty (nawet w obrębie jednej serii) bardzo niejednorodne semantycznie. I to właśnie ich opis semantyczny nastręcza największych trudności.

Analizowane struktury realizują co najmniej kilka tendencji językowych. Polskie composita bezafiksalne stanowią niewątpliwie wyraźny przejaw tendencji do inter- 
nacjonalizacji słowotwórstwa i w taki sposób są postrzegane przez językoznawców². Obecność w języku modeli słowotwórczych charakteryzujących się wysokim stopniem aktywności jest uznawana za przejaw działania ekonomii językowej. W tym miejscu należałoby zwrócić uwagę na dodatkowy czynnik (poza wysoką frekwencją), który w jeszcze większym stopniu decyduje o wpisaniu omawianego modelu słowotwórczego w zakres działania tendencji do ekonomii językowej. Chodzi mianowicie o tendencję do automatyzacji technik derywacyjnych (por. Jadacka 2005: 104). Natomiast obserwacje dotyczące funkcjonowania tego typu złożeń w tekstach dziennikarskich udowadniają, że wyrazy te nie wpisują się jednoznacznie w zakres oddziaływania tendencji do precyzji informacji bądź precyzji semantycznej struktur wyrazowych, zwłaszcza w języku mediów. Wręcz przeciwnie, o ich użyciu w tekstach dziennikarskich decyduje przede wszystkim semantyczna niedookreśloność, zwłaszcza pierwszego z komponentów. Najczęściej są to złożenia rzeczownikowe, które pozornie dają się zastąpić frazą nominalną, w rzeczywistości jednak często się okazuje, że przełożenie to jest nieuzasadnione właśnie ze względu na brak semantycznej przejrzystości derywatu.

Na użytek niniejszego artykułu właśnie brak przejrzystości semantycznej derywatu, a tym samym jego semantyczna niedookreśloność (niejednoznaczność) rozumiane są jako przejaw dyfuzji semantycznej, zgodnie z przyjętym za A. Kiklewiczem poglądem:

Dyfuzję semantyczną definiujemy jako niedookreślenie czy też niezdeterminowanie treści znaków językowych różnego formatu (morfemów, leksemów, grup wyrazowych, zdań, tekstów), rozmyty charakter granic między znaczeniami i kategoriami znaczeniowymi w semantycznym systemie języka oraz w komunikacji językowej (Kiklewicz 2006a: 12).

Dyfuzja semantyczna w słowotwórstwie języka mediów jest zjawiskiem często spotykanym, w szczególnym zaś stopniu dotyczy to najnowszych wyrazów złożonych z pierwszym komponentem obcym, które wykazują dużą frekwencję w strategicznych miejscach w tekście, tj. zwłaszcza w nagłówkach artykułów. Sprzyja temu kompozycyjny charakter derywatów. Jak bowiem wiadomo,

[...] kompozycyjny charakter semantyki leksykalnej jest względny, ponieważ często sama wiedza językowa o znaczeniu tematu bazowego i formantu słowotwórczego nie jest wystarczająca, aby w sposób adekwatny i zgodny z konwencją językową określić znaczenie derywatu (Kubrjakowa, cyt. za: Kiklewicz 2006a: 13, por. Kubrjakowa 2004).

W szczególny sposób właściwość ta dotyczy omawianych tutaj compositów. Struktura derywatów, znaczenie komponentów wchodzących w skład konstrukcji

2 Pisała na ten temat m.in. Krystyna Waszakowa (2003, 2005). 
oraz typ relacji między nimi wskazują na pewną ogólną ramę semantyczną, „natomiast o konkretyzacji znaczenia derywatu decyduje inferencja - aktualizacja kontekstowo relewantnej wiedzy o świecie" (Kiklewicz 2006a: 13). Ta cecha złożeń powoduje, że próby aktualizacji ich znaczenia oparte na tradycyjnych metodach słowotwórstwa strukturalistyczno-semantycznego mogą stać się jedną z przyczyn zakłóceń w odbiorze znaczenia tak skonstruowanych wyrazów, ponieważ każą nam je interpretować jako dość jednoznaczne (wyraz tendencji do precyzji znaczeniowej (Buttler, Kurkowska, Satkiewicz 1986: 105)) i nieskomplikowane w planie treści. Rzeczywistość językowa (zwłaszcza medialna) pokazuje jednak zupełnie inny stan rzeczy. Współczesne teksty dziennikarskie nasycone są wszelkiego typu aluzjami i odsyłają odbiorcę do mnóstwa incydentalnych faktów, których nieznajomość wyłącza z komunikacji osoby niewtajemniczone. Oprócz tego do zjawisk powszechnych i celowych we współczesnej rzeczywistości komunikacji medialnej należy emocjonalizacja dyskursu publicznego. Z kolei osiągnięciu efektu emocjonalizacji języka służy między innymi swoisty synkretyzm języka mediów, polegający na mieszaniu w nim różnych odmian języka, chodzi zwłaszcza o korzystanie z resursów języka potocznego ${ }^{3}$. Wszystko to powoduje, że do zrozumienia wielu skondensowanych, ale złożonych derywatów słowotwórczych koniecznie potrzebny okazuje się dostęp do określonych domen wiedzy. Znaczenie wielu nowych compositów z pierwszym komponentem obcym jest konstytuowane i ujawnia się w ramach danego tekstu, tj. w konkretnym kontekście. A. Kiklewicz wiąże zjawisko tzw. kontekstocentryzmu języka mediów z zależnościami wynikającymi z relatywizmu kulturowego, znajdującymi odzwierciedlenie na różnych płaszczyznach funkcjonowania języka i językowej działalności człowieka (por. Kiklewicz 2012). Z jednej strony następuje zacieśnienie związku języka z kontekstem (nie jest możliwe dotarcie do znaczenia bez znajomości szerokiego kontekstu lub nawet więcej - nieznajomość kontekstu może powodować lukę komunikacyjną), z drugiej natomiast dochodzi do rozluźnienia związku języka z kontekstem (znaczenia mogą pojawiać się w nieoczekiwanych kontekstach i w znanych kontekstach mogą zostać wykreowane nowe znaczenia). Są to mechanizmy, na których opiera się programowy postmodernistyczny postulat niejednoznaczności.

Uwzględniając powyższe rozważania, przyjrzyjmy się kilku wybranym derywatom ${ }^{4}$. Zarówno w języku polskim, jak i w innych językach słowiańskich można za-

3 Kazimierz Ożóg pisze o „ekspansywnej potoczności” w języku oficjalnych wypowiedzi (por. 2011: 52-88).

4 Zaprezentowany w artykule materiał językowy pochodzi z własnego korpusu tekstów prasowych, gromadzonych w latach 2000-2015. Pochodzą one zwłaszcza z prasy wysokonakładowej (głównie wydań on-line) oraz portali internetowych o różnych profilach tematycznych. Wyboru konkretnych derywatów dokonałam ze zbiorów obejmujących co najmniej 200 użyć językowych struktur słowotwórczych określonego typu (np. różnych derywatów z pierwszym komponentem $e$ - itd.). Kolejnym kryterium decydującym o doborze trzech konkretnych derywatów dla zilustrowania 
obserwować wzrost liczby derywatów z pierwszym członem zdezintegrowanym e-, co niewątpliwie znajduje przyczynę w niezwykle szybkim rozwoju technologii informatycznych i coraz częstszym korzystaniu z różnego typu narzędzi internetowych. O budowie słowotwórczej tego typu złożeń, o ich produktywności, o statusie pierwszego komponentu złożenia, a także o relacjach, jakie zachodzą między komponentami w języku polskim, pisze wielu badaczy ${ }^{5}$. Niedookreślony charakter znaczenia tego typu derywatów w tekstach i wypowiedziach dziennikarskich udowadniam na wielu przykładach zarówno polskich, jak i bułgarskich złożeń w artykule $O$ zmianach $w$ polskim i bułgarskim systemie słowotwórczym na przykładzie złożeń $z$ komponentami e- oraz интернет- $i$ онлайн- (por. Długosz 2015a: 55-58). W tym miejscu posłużę się jednym przykładem compositum, trudnym do zinterpretowania poza granicami tekstu. Chodzi mianowicie o odnotowany w nagłówku tekstu prasowego derywat e-szambo.

(1) Ekshibicjonizm elit 2.o, czyli intelektualistów skok do e-szamba

Celebrycka zaraza medialnego handlowania prywatnym życiem sięgnęła wyżyn. I to tych intelektualnych, bo do publicznego prania domowych brudów wzięli się przedstawiciele elit. Dziś granica między tym, co publiczne, a tym, co prywatne, zniknęła. A wraz z nią poczucie dobrego smaku.

W środowisku intelektualnym zawrzało. Miniskandal rozbudził rozespany świat, który do tej pory rzadko lądował na tabloidowym Pudelku. Trafił tam kilka dni temu. Wydarzenia, którego bohaterami, ale i autorami, stali się pisarz Ignacy Karpowicz oraz krytyczka literacka Kinga Dunin, nie tylko uruchomiły lawinę plotek, lecz także po raz kolejny zmusiły do postawienia pytania: co przystoi elicie? Na co mogą sobie pozwolić ci, którzy przynależą do świata kultury, bądź co bądź, wysokiej, a przynajmniej do tej pory w takiej roli się ustawiali - Kinga Dunin nadawała ton debacie publicznej dotyczącej polskiego feminizmu, Ignacy Karpowicz otrzymał Paszport Polityki, a obecnie drugi raz był nominowany do znanej Nagrody Literackiej Nike.

Znalazły się tu wszystkie elementy klasycznej opery mydlanej: pieniądze, seks, gwałt oraz robienie kariery przez łóżko. Obydwoje poszli na całość. Najpierw

zjawiska dyfuzji semantycznej była ich frekwencja w zgromadzonym korpusie tekstów (ponad kilkanaście użyć) oraz wielość profili semantycznych, w jakich występowały. Z całą pewnością analiza zjawiska dyfuzji semantycznej w języku mediów na większej liczbie przykładów compositów bezafiksalnych z różnymi pierwszymi komponentami wzbogaciłaby badanie, czyniąc je bardziej wiarygodnym. Wysunięte w artykule wnioski zostały jednak oparte na reprezentatywnym (bo liczącym dziesiątki, a nawet setki jednostek) materiale językowym, którego nie sposób uwzględnić w tym miejscu.

5 W języku polskim o compositach z pierwszym komponentem $e$ - pisali m.in. Jolanta Kowalewska-Dąbrowska (2011), Małgorzata Bortliczek (2013), Halina Mieczkowska (2014), Natalia Długosz (Długosz 2015b). 
ona na swoim profilu na Facebooku oskarżyła Karpowicza, że nie oddał jej 13 tys. zł, a na jej grzeczne prośby o zwrot pieniędzy odpowiedział: „S...dalaj”. Już kilka godzin później kilka feministek poparło Dunin, ogłaszając bojkot środowiskowy, przekonując, że nie podałoby ręki pisarzowi. Akcja rozwijała się szybko - autor Ości odpowiedział z przytupem. Oskarżył Dunin nie tylko o regularne molestowanie seksualne, lecz także o gwałt. Napisał o tym w długim liście, również opublikowanym na Facebooku. Na marginesie dodał, że przelał jej już pieniądze.

(http://wiadomosci.dziennik.pl/opinie/artykuly/471412,ekshibicjonizm-elit2-o-czyli-o-karpowiczu-dunin-i-intelektualistach.html; dostęp: 5 III 2016)

Odnotowane w nagłówku compositum e-szambo ani razu nie zostało przywołane w tekście właściwym artykułu. Derywat ten należy niewątpliwie do struktur o dużym stopniu zagęszczenia semantycznego i potencjalnie może być odczytany na różne sposoby, jak choćby:

1. 'elektronicznie sterowany zbiornik, do którego spływają ścieki z kanalizacyjnych urządzeń domowych, analogicznie do wielu oferowanych na rynku e-instalacji';

2. 'istniejące $\mathrm{w}$ przestrzeni wirtualnej specjalne miejsce przechowywania, składowania śmieci elektronicznych, np. plików, zbędnych dokumentów w wersji elektronicznej'.

Z przytoczonego jako kontekst tekstu dziennikarskiego wynika jednak zupełnie inne znaczenie, mianowicie derywat e-szambo może wskazywać na 1. 'przestrzeń wirtualną (np. portale społecznościowe lub odpowiednio profilowane portale plotkarskie), w której zamieszczane są wiadomości moralnie dwuznaczne', lub 2. (co bardziej prawdopodobne) na 'zaistniałą w rzeczywistości wirtualnej niemoralną, nieprzyzwoitą, nieobyczajną sytuację’. Zatem dla właściwego zrozumienia leksemu konieczne okazuje się „przywołanie [...] wiedzy o świecie (w tym wiedzy kulturowej) wraz z rozmaitymi konotacjami przypisywanymi obiektom, do jakich odnosi się dane wyrażenie" (Waszakowa 2003: 417). W tym wypadku chodzi o przenośne, potoczne znaczenie leksemu szambo jako 'sytuacji podejrzanej, dwuznacznej moralnie’. Zamieszczone w nagłówku artykułu niepozorne złożenie e-szambo pełni co najmniej dwie funkcje pragmatyczne. Po pierwsze stanowi swoistą ,zagadkę semantyczną", która zachęca czytelnika do rozwiązania, czyli przeczytania tekstu artykułu (por. Szumska 1999: 22) i po drugie zawiera negatywną ocenę zjawiska, do której obrazu odsyła derywat, służy zatem ekspresywizacji tekstu.

$\mathrm{Z}$ podobnym zabiegiem mamy do czynienia w wypadku wielu derywatów złożonych, również z komponentem euro-. Na niejednoznaczny charakter tego typu compositów zwróciła uwagę m.in. Krystyna Waszakowa (2003: 416-417), a o pozornej wyrazistości znaczeniowej tego typu złożeń pisze także N. Długosz (2013: 190-195). Dla zilustrowania problemu posłużę się przykładem leksemu stosunkowo często występującego w tekstach dziennikarskich - chodzi o derywat eurotrum- 
na. Jak wiadomo z wcześniejszych analiz tekstologicznych na wyrazach złożonych zarówno w języku polskim, jak i w innych językach słowiańskich znaczenie przypisywane komponentowi euro- (formułowane najczęściej w postaci tautologiczno-metonimicznej definicji odsyłającej do rzeczownika Europa lub przymiotnika europejski) w tradycyjnych słownikach objaśniających nie wyczerpuje bogactwa jego semantycznych odniesień. W języku polskim propozycję rozbudowanej definicji, opartej na analizie tekstologicznej derywatów, przedstawiła Donata Ochmann, wskazując, że komponent euro- w compositach może oznaczać:

1. związek drugiego członu z Europą, zwłaszcza Zachodnią, jako wspólnotą kulturową i cywilizacyjną, a także z Unią Europejską, jej strukturami i walutą [...]; 2. związek drugiego członu z Europą jako kontynentem [...]; 3. określony wysoki standard, nowoczesność tego, co nazywa drugi człon [...] (Ochmann 2004: 139).

Również K. Waszakowa wskazuje na trzy zakresy znaczeniowe komponentu euro-: euro $I \leftarrow$ Europa, europejski, por. eurobezpieczeństwo, eurosport; euro II $\leftarrow$ Unia Europejska, por. eurodeputowany, eurosubwencje; euro III $\leftarrow$ euro 'waluta Unii Europejskiej', por. euromoneta, eurozłoty (Waszakowa 2005: 76, 78). Zjawisko dyfuzji semantycznej wielu tego typu derywatów doskonale ilustrują odnotowane w polskiej prasie artykuły, zawierające derywat eurotrumna. Potencjalnie, jeśli będziemy interpretować komponent euro- $\mathrm{w}$ ramach zaproponowanych przez Ochmann lub Waszakową obszarów semantycznych odniesień, leksem ten można rozumieć na kilka sposobów, np. jako:

1. 'trumna produkowana na terenie Europy, w krajach Unii Europejskiej';

2. 'trumna spełniająca wymagania stawiane przez Unię Europejską, trumna spełniająca europejskie standardy jakości';

3. 'trumna, za którą należność uiszczono w europejskiej walucie euro'.

Tak skonstruowane, założone a priori, domyślne znaczenia derywatu nie wyczerpują wszystkich możliwości. Przyjrzyjmy się kilku przykładom użycia derywatu w tekście.

(2) Dlaczego Polska chce wejść do e u rot r u m ny?

Choć Polska nie jest w strefie euro i zapewne nigdy do niej nie przystąpi, to rząd deklaruje gotowość przyjęcia niemieckiej propozycji „unii fiskalnej”. Jak na razie nie usłyszeliśmy odpowiedzi na podstawowe pytanie: co z tego będziemy mieli?

Strefa euro chwieje się w posadach. Włochy balansują na krawędzi wypłacalności zagrażając istnieniu całego europejskiego sektora bankowego. Władcy państw Eurolandu chcą uniknąć upadku politycznego projektu, jakim jest europejska unia walutowa, ale wyraźnie brakuje im rozeznania w sytuacji. Rynek i rzeczywistość gospodarcza zawsze są o dwa kroki przed politykami.

(www.bankier.pl/wiadomosc/Dlaczego-Polska-chcewejsc-do-eurotrumny-2449315.html; dostęp: 27 II 2016) 


\section{(3) Europa na opak}

Wielka Unia czuwa. Wdziera się do kurnika, by stemplować jajka w zależności od miejsca ich zniesienia, walczy z krzywizną banana, ba, stara się nawet ujednolicić wymiary trumien. Czego oni nie wymyślą w tej Brukseli...

Do eurotrumny marsz! Jeden z powszechnie cytowanych euromitów mówi o tym, że Komisja Europejska naciska, aby ujednolicić rozmiary trumien w całej Unii Europejskiej. W rzeczywistości podjęto tylko próbę wprowadzenia minimalnych standardów jakości i wytrzymałości trumien.

(„Magazyn” nr 39, dodatek do „Gazety Wyborczej”

nr 226, 27 IX 2001)

\section{(4) Eurotrumna}

„Poland's wunderwaffe strikes back. Nasz odwet na BBC” - napisał na Twitterze minister Radosław Sikorski, dowcipnie komentując zdjęcie Natalii Siwiec. Ta „cudowna broń Polski w odwecie” postanowiła zemścić się na BBC i Solu Campbellu. Podczas półfinałowego meczu Niemcy - Włochy Natalia wystąpiła w koszulce z oryginalnym rozwinięciem skrótu BBC, a mianowicie napisem „Bad Boy Campbell”, czyli po naszemu „zły chłopiec Campbell”. - Zareagowałam, bo wypowiedź piłkarza naprawdę mnie dotknęła. Film BBC zobaczyłam tuż po wylądowaniu w Warszawie. Nie było mnie w kraju ponad trzy lata. Wracam dumna, bo trafiłam akurat na największą imprezę w naszej historii, a tu słyszę faceta, który straszy, że Polska to dziki kraj, że z naszego Euro zagraniczni kibice wrócą w trumnach. Wkurzyłam się. Naprawdę opowiada Natalia.

Trumny, którymi straszył Sol Campbell, nie przestraszyły brytyjskich kibiców.

(„Wprost” nr 27, 2-8 VII 2012)

Z przytoczonych powyżej fragmentów tekstów dziennikarskich wyłaniają się trzy zupełnie różne znaczenia compositum eurotrumna:

1. 'upadek strefy euro' lub 'ostateczna klęska, niepowodzenie, upadek koncepcji integracji walutowej w ramach Unii Europejskiej / porażka idei europejskiej unii walutowej';

2. 'trumna jako produkt spełniający standardy jakości i wytrzymałości ustanowione przez Komisję Europejską';

3. 'trumna, w której mogłyby być transportowane zwłoki zagranicznych kibiców (narażonych na utratę życia) z odbywających się w Polsce w 2012 r. mistrzostw Europy w piłce nożnej'.

Komponent euro- w każdym z użyć derywatu odnosi się do różnych elementów rzeczywistości: 1. do strefy euro; 2. do europejskich standardów jakości i wytrzymałości; 3. do mistrzostw Europy w piłce nożnej EURO 2012. Zaproponowane definicje nie wyczerpują pełnego obrazu zjawisk, do których derywaty się odnoszą. Poza nie- 
dookreślonością semantyczną pierwszego komponentu złożenia właściwą interpretację znaczenia wyrazu dodatkowo utrudnia użycie rzeczownika trumna w znaczeniu nie dosłownym, a przenośnym, opartym na szerokich konotacjach tego wyrazu. Jest to widoczne zwłaszcza w pierwszym tekście, w którym o konkretyzacji znaczenia derywatu decyduje aktualizacja określonych zasobów wiedzy kulturowej. Trumna bowiem kojarzy się ze śmiercią, a więc niesieniem definitywnego końca, a także z klęską, upadkiem, niepowodzeniem. Ścieżka dostępu do domeny ujętej w opartym na konwencji związku wyrazowym pozwala na zaktualizowanie znaczenia derywatu. W tym wypadku mowa o mocno ustabilizowanym w języku polskim frazeologizmie gwóźdź do trumny / wbić gwóźdź do trumny w znaczeniu 'ostateczna przyczyna upadku, klęski, niepowodzeń itp.' / 'przyczynić się do porażki, klęski, upadku czegoś, kogoś' (SFWP). Również w trzecim z przywołanych tekstów dotarcie do pełnej treści derywatu staje się możliwe dzięki konotowanemu znaczeniu leksemu trumna, kojarzonego ze śmiercią, poczuciem zagrożenia i niebezpieczeństwem. We wszystkich zacytowanych fragmentach tekstów dziennikarskich dodatkowym czynnikiem decydującym o atrakcyjności derywatu jest kontrastowe zestawienie komponentów. Komponent euro- $\mathrm{w}$ wielu derywatach wnosi bowiem znaczenie pozytywnie wartościujące, tj. wskazuje na wysoki standard, nowoczesność ( $\mathrm{z}$ tego względu popularność komponentu euro- jako pierwszego członu nazw własnych przedsiębiorstw). Z kolei leksem trumna ma w języku polskim jednoznacznie negatywne konotacje. We wszystkich trzech wypadkach użyć wyrazów całość obrazu dopełnia negatywna, wyraźnie ironiczna ocena zjawiska, która ma na celu uwypuklenie sytuacyjnego absurdu. Odczytanie ujętej w derywatach, profilowanej oceny możliwe jest w określonym kontekście i wyłącznie wówczas, gdy mamy określoną wiedzę sytuacyjną i kulturową.

Analiza tekstów dziennikarskich udowadnia także semantyczną niedookreśloność derywatów z wieloma innymi komponentami. Problem ten dotyczy zwłaszcza dość ekspansywnych w dyskursie publicznym złożeń z pierwszym komponentem eko-. Magdalena Steciąg (2012: 90-92) pisze nie tylko o dyfuzji semantycznej komponentu eko-, ale wręcz o jego „semantycznej degradacji” (ibid.: 108), a zawierające go composita zalicza do wyrazów tworzących „tzw. ecobabble, czyli ekopaplaninę, która nic nie znaczy" (ibid.: 75). Podkreśla ponadto, że taka sytuacja powoduje nie tylko nieporozumienia, ale także nadużycia. O tym, że omawiany typ formacji może posłużyć jako łatwe narzędzie manipulacji, pisała także N. Długosz (2015b):

[...] w wielu strukturach komponent ten [eko- - N.D.] traci zawartość znaczeniową $\mathrm{w}$ sensie denotacji, natomiast niesie ze sobą pewien sąd aksjologiczny. Można wręcz pokusić się o pogląd, że eko- staje się swego rodzaju emotywnym operatorem, który ułatwia manipulację znaczeniem (ibid.: 344 ).

Zjawisko dyfuzji semantycznej zilustrowane tutaj na kilku zaledwie przykładach compositów z pierwszym obcym komponentem w tekstach dziennikarskich $\mathrm{z}$ całą pewnością nie ogranicza się wyłącznie do wymienionych w artykule serii 
derywatów. Można z powodzeniem mówić o nim także w stosunku do innych złożeń, często występujących $\mathrm{w}$ tekstach prasowych, jak choćby $\mathrm{w}$ odniesieniu do wyrazów z pierwszym komponentem art-, cyber-, homo-, gej-, narko-, porno-, petro- i innych. Wszystkie tego typu derywaty łączy referencjalna nieprzezroczystość pierwszego komponentu złożenia, która de facto staje się przyczyną semantycznego niedookreślenia całej formacji. Myślę, że pogląd M. Steciąg (2012: 90) o niemożliwości jednoznacznej interpretacji semantycznej derywatów z pierwszym komponentem eko- można śmiało rozszerzyć na inne serie compositów z pierwszym członem obcym. W tych wypadkach bowiem

[...] konkretne znaczenia aktualizują się w konkretnych sytuacjach komunikacyjnych i są motywowane dyskursywnie, tzn. wymagają uwzględnienia standardów semantycznych (wyznaczających wartościowanie, konotacje, otoczkę pragmatyczną, kontekst jednostek), które obowiązują w danej wspólnocie [...] (ibid.: 91).

Te charakterystyki decydują o umieszczaniu podobnych formacji zwłaszcza w nagłówkach tekstów dziennikarskich. To dzięki semantycznej niedookreśloności mogą one skutecznie pełnić szereg funkcji pragmatycznych, choćby takich jak:

[...] 1. dążenie nadawcy do wyrażenia własnych stanów emocjonalnych, nastawienia wobec przekazywanej informacji semantycznej (w tym także elementów oceny) oraz nadania tekstowi cech indywidualnych [...];

2. dążenie nadawcy do kształtowania zachowań (zwłaszcza mentalnych) odbiorcy $[\ldots]$;

3. aktywizowanie kompetencji kulturowych nadawcy i odbiorcy determinowane zewnętrznymi okolicznościami komunikacji, bez których udziału niemożliwe jest rozumienie derywatu. Przy czym szczególną rolę przypisuję udziałowi kontekstu w komunikacji (Długosz, w druku).

\section{Literatura}

BoRTLICZeK M., 2013, Jęzkowe obrazy świata (wirtualny i realny) kreowane przez formacje $z$ e- $i$ eko-, [w:] E. Badyda, J. Maćkiewicz, E. Rogowska-Cybulska (red.), Słowotwórstwo w różnych odmianach języka. Materiały piątej konferencji językoznawczej poświęconej pamięci profesora Bogusława Krei, „Wokół słów i znaczeń”, t. V, Gdańsk, s. 189-208.

Buttler D., Kurkowska H., Satkiewicz H., 1986, Kultura języka polskiego, Warszawa.

DŁugosz N., 2013, Kognitywna interpretacja najnowszych złożeń z powtarzalnym $w$ serii wyrazów członem zwiazanym (na przykładach $z$ języka polskiego i bułgarskiego), „Slavia Meridionalis" XIII: Składniowe metody w stowotwórstwie, s. 187-200.

D£UGosz N., 2014, Няколко бележки относно словообразувателната аналогия в славянското езикознание (в контекста на най-новите безафиксални сложни думи 
в полския и българския език), „Научни трудове” „Филология” t. 6о, z. 1, сz. А, S. $402-416$.

DŁUgosz N., 2015a, O zmianach w polskim i bułgarskim systemie słowotwórczym na przykładzie złożeń z komponentami e- oraz интернет- $i$ онлайн-, [w:] A. Kovacheva, P. Borowiak, Bułgaria tradycyjna i nowoczesna, Poznań, s. 51-60.

DŁUGosz N., 2015b, Język jako narzędzie kształtowania postaw proekologicznych - o polskich $i$ bułgarskich złożeniach z komponentem eko- $w$ dyskursie publicystycznym, „Poznańskie Studia Slawistyczne” nr 8, s. 333-348.

DŁugosz N., w druku, Najnowsze polskie i bułgarskie composita jako przejaw derywacji pragmatycznej $w$ tekstach dziennikarskich (na wybranych przykładach), [w:] Słowotwórstwo języka mówionego i pisanego, „Wokół słów i znaczeń”, t. VI, Gdańsk.

JADACKA H., 2005, System słowotwórczy polszczyzny (1945-200o), Warszawa.

Kaproń-CharzyńsKa I., 2007, Pragmatyczna funkcja formantów w opisie derywatów, „Biuletyn Polskiego Towarzystwa Językoznawczego" LXIII, s. 147-156.

Kiklewicz A., 2006a, Dyfuzja semantyczna w języku i tekście I, „LingVaria” nr 1 (1), s. 11-21.

KiKlewicz A., 2006b, Dyfuzja semantyczna w języku i tekście II, „LingVaria” nr 2 (2), s. 9-20.

KiklewiCz A., 2012, Czwarte królestwo. Język a kontekst w dyskursach współczesności, Warszawa.

Kowalewska-DĄBrowska J., 2011, Przejawy inwencji słowotwórczej w języku prasy ostatnich lat (na przykładzie wybranych gazet i czasopism), [w:] E. Badyda, J. Maćkiewicz, E. Rogowska-Cybulska (red.), Słowotwórstwo a media, „Wokół słów i znaczeń”, t. IV, Gdańsk, s. 61-68.

KubrJakowa Je.S [= Кубрякова E.C.], 2004, Язык и знание. На пути получения знаний о языке: части речи с когнитивной точки зрения. Роль языка в познании мира, Москва.

KudRa B., 2011, O tzw. derywacji pragmatycznej i derywatach pragmatycznych (Słowotwórstwo a pragmatyka), [w:] E. Badyda, J. Maćkiewicz, E. Rogowska-Cybulska (red.), Słowotwórstwo a media, „Wokół słów i znaczeń”, t. IV, Gdańsk, s. 13-18.

MieczкowsкA H., 2014, E-kompozita czy e-zestawienia? (na materiale słowacko-polskim), „Rocznik Slawistyczny” LXIII, s. 77-89.

Ochmann D., 2004, Nowe wyrazy złożone o podstawie zdezintegrowanej, Kraków.

OżóG K., 2011, Polszczyzna przełomu XX i XXI wieku. Wybrane zagadnienia, Rzeszów.

Rogowska-Сyвulska E., 2013, Słowotwórstwo na usługach reklamy. Mechanizmy tekstowe, Gdańsk.

SFWP: S. Bąba, J. Liberek, Słownik frazeologiczny współczesnej polszczyzny, Warszawa 2002. SteciąG M., 2012, Dyskurs ekologiczny w debacie publicznej, Zielona Góra.

Szumska D., 1999, Niebezpieczne związki, czyli meandry adiektywizacji, [w:] A. Kiklewicz (red.), Паланістыка - Полонистика - Polonistyka, Мінск, s. 4-28.

WaszaKowa K., 2003, Kognitywne aspekty tworzenia nowych derywatów słowotwórczych (na przykładzie języka polskiego), [w:] I. Ohnheiser (red.), Słowotwórstwo/Nominacja. Komparacja systemów i funkcjonowania współczesnych języków słowiańskich, Opole, s. 411-435.

Waszakowa K., 2005, Przejawy internacjonalizacji w słowotwórstwie współczesnej polszczy$z n y$, Warszawa. 


\section{On semantic diffusion in journalistic texts, using the example of selected Polish compounds where the first element is foreign Summary}

The article focuses on the signs of semantic diffusion in word formation in the context of the indeterminate nature of many Polish compounds in which the first element is foreign, such as those with the component e-, euro-, or eco-. Derivatives are investigated in terms of their context, i.e. emphasis is put on their updated meaning in specific uses in journalistic texts. The phenomenon is analysed in connection with the pragmatic aspect of word formation in the language of the mass media. 